\title{
"Let Me Enjoy Teaching" \\ Improving Academic Quality Assurance Practices to Attain Teaching Excellence: Case Study of Selected Private Higher Education Institutions in the Kingdom of Saudi Arabia
}

\author{
Randa Hariri \\ Dar Al Hekma University, Jeddah, Saudi Arabia \\ https:/ /orcid.org/0000-0002-6636-6190
}

\begin{abstract}
The purpose of this study was to identify the academic quality assurance practices that should be employed to attain teaching excellence at selected private higher education institutions in the city of Jeddah, Saudi Arabia. The study adopted a qualitative interpretive research design and utilized one-to-one, in-depth, semi-structured interviews with 12 participants. The sample was purposefully selected and comprised six faculty members, four program directors, one senior academic staff member, and one junior non-academic administrator, from three private higher education institutions in the Kingdom of Saudi Arabia. Findings revealed four categories of practices: a) Must-keep practices, b) Mustmodify practices, c) Must-add practices, and d) Must-avoid practices. Some of the practices relating to quality assurance that the study identified are maintaining important evaluation-related practices while providing feedback for improvement, closing the loop, educating all employees about and increasing their reengagement in quality assurance practice, and reducing paperwork and work duplication. This study concludes by recommending that higher education institutions employ the strategies discussed in the findings to promote teaching creativity and to improve the quality of teaching and learning, to achieve teaching excellence.
\end{abstract}

Keywords: academic quality assurance; higher education; private higher education institutions; teaching excellence

\section{Introduction}

The management bodies of higher education institutions are becoming more interested in quality assurance. This interest could impose a burden of extra work on teachers, which could lead to burnout, a loss of interest in the profession, and even teachers quitting their positions (A-Maawali \& Al-Siyabi, 2020). Quality 
assurance processes and practices are becoming increasingly significant in higher education institutions in the Kingdom of Saudi Arabia (KSA), in particular. This significance has two manifestations. The first is related to the establishment of the National Commission for Academic Accreditation and Assessment (NCAAA) in 2004, as a quality assurance body assigned to accredit private higher education institutions at institutional and program levels. This body was housed under the Education and Training Evaluation Commission (ETEC) in 2018, and is intended to process and accomplish all tasks related to quality assurance in the KSA. This expansion occurred in response to the massification and internationalization of tertiary education, whereby the number of higher education institutions in the Kingdom increased to 29 public universities and 14 private universities, according to 2018 statistics (Allahmorad \& Zerik, 2020; Bollaert, 2014). The second manifestation is related to providing students with good quality teaching and learning opportunities, so that, when they graduate, they can pursue further studies at national and international higher education institutions, or perform well in the labor market (Anane \& Addaney, 2016).

At accredited universities, quality assurance plays a central role in meeting the requirements of the national accrediting body of the KSA - the context of this study - as well as the aspirations of all stakeholders. This research study's challenge was investigating quality-assurance-related procedures, such as the evaluation and the measurement processes of the various teaching and learning objectives. These processes are criticized for being lengthy, highly demanding, exhausting, excessively bureaucratic, and time consuming (Seyfried \& Pohlenz, 2018). Seyfried and Pohlenz (2018) explicitly add that academic staff consider quality-assurance-related procedures to be more of a burden than an opportunity, and they consider it draining. This attitude is mainly the result of the time required by the assessment processes of numerous tasks and performances, as well as the need to produce and collect pieces of evidence to submit to accrediting bodies as proof of the quality of their work. This type of work is found to compete for time that teachers are supposed to devote to thinking about and reflecting on their teaching, and related tasks that help to attain and maintain high quality teaching and achieving teaching excellence (Brookfield, 2017).

The literature is rich in studies about quality assurance and improvement practices (A-Maawali \& Al-Siyabi, 2020; Anane \& Addaney, 2016; Bollaert, 2014; Cheng, 2015; Tandberg \& Martin, 2019), but there is limited literature on improving these practices in higher education institutions in the KSA - this is a research gap. Therefore, this research study comprises an attempt to contribute to closing this research gap by investigating the quality-assurance-related practices that should be implemented in private higher education institutions in the KSA to effectively enhance the quality of teaching.

\subsection{Research Purpose}

The purpose of this study was to explore the perceptions of academic and nonacademic staff members of higher education institutions on academic quality, evaluation of existing practices, and the means that could be used to improve these procedures. This upgrade is necessary to improve the quality of teaching 
and, thus, attain teaching excellence. The significance of exploring the perceptions of academic and non-academic staff on general academic quality emerges from the idea that staff perceptions guide their practices. The results of this research study could aid policymakers in higher education to develop or review existing policies and procedures, and improve quality assurance practices. Furthermore, the findings of this research study could inform the upper and middle management at higher education institutions, to encourage them to implement the suggested improvement practices for teaching. This benefit is particularly significant, as it emphasizes a bottom-up model that appraises the engagement of employees in improving existing and developing new quality assurance practices.

The research questions that this study answered are a) How do academic and nonacademic staff perceive academic quality, and b) How do academic and nonacademic staff believe quality assurance practices at higher education institutions can be improved?

\section{Literature Review}

\subsection{Quality Assurance Defined}

The significance of quality assurance and related practices is expressed well in the following definition of quality assurance: "Quality assurance in higher education is increasingly used to denote the practices, whereby academic standards, i.e., the level of academic achievement attained by higher education graduates, are maintained and improved" (Dill, 2010, p. 377). This definition recaps the main academic quality assurance practices, which are mainly manifested in measuring or evaluating the achievement of students and graduates of higher education institutions, while relying on pre-set standards and criteria, and maintaining the level of the quality of these achievements throughout the whole process of tasks.

For Brittingham (2009), quality assurance comprises everything a higher education institution must undertake to provide high-quality education, whereas quality improvement is the framework or roadmap for institutional advancement and self-evaluation of what a higher education institution must do. The Finnish Higher Education Evaluation Council views quality assurance as comprising all procedures used by a higher education institution to develop and improve teaching, learning, and all available services that are designed to fulfil an education institution's principal aim (FINHEEC, 2008). Mishra (2007) categorizes quality assurance into three parts. The primary part involves all the systems being utilized to improve the quality of instruction and learning. Another part involves all the procedures and techniques used to monitor the quality that is accomplished. The third part incorporates all types of assistance received from upper administration to improve and maintain the legitimacy and functionality of the quality assurance framework.

From another point of view, Biggs (2001) considers quality in two different ways: retrospectively or prospectively. A retrospective view of quality is observed when economic prerequisites are met. A prospective view of quality includes fulfilling the reason for the university's existence as far as changing students' impression of the world and their capacity to use the knowledge they procure to settle on 
choices and to safeguard their interests. Hénard (2010) appears to concur with Biggs' (2001) retrospective impression of quality assurance, since he believes quality is a powerful idea that fluctuates with relevant necessities and natural changes. This implies that policymakers ought to avoid setting fixed models and inflexible norms for instructors to follow and achieve. All measures and norms, according to Biggs (2001), should be flexible and adaptable enough to adjust in accordance with changes in the environment. Filippakou (2011) takes this idea further by offering a reasonable methodology - as opposed to a definition - to investigate understandings of the quality of work at higher education institutions, and the quality of educating and learning, specifically, of various stakeholders, including instructors. Appropriately, Filippakou considers the idea of quality as an "ideological" development that lies at the core of the "discourses" teachers attempt. In the absence of consensus on the definition of quality, due to subjectivity regarding quality, definitions of quality differ from one context to another.

In relation to the distinction between prospective and retrospective aspects of quality assurance frameworks, quality assurance and quality enhancement are compatible with a retrospective impression of quality. This is made clear by quality assurance frameworks that predominantly rely on ensuring teaching quality being measured by fulfilling predetermined guidelines. In any case, a prospective meaning of quality is sought, to assist students at higher education institutions to make smarter decisions at their education institutions, and ultimately in their societies. Filippakou's (2011) impression of quality as an ideological development means quality ought to be in educators' hearts, should manage their practices from the inside, and should advance their scholarly freedom.

Basic examination deconstructs current quality assurance and quality enhancement practices and uncovers the beliefs and qualities supporting them. For instance, Skelton (2012) accepts that the developing pattern of quality assurance and quality enhancement is associated with neo-liberalism and marketization, which was introduced to the education sector by the commercial sector. He contends that an emphasis on quality assurance and quality enhancement is harming the quality of work of educators at higher education institutions, who are expected to execute two extra duties in addition to instructing, namely research and managerial work. Quality assurance and quality enhancement processes compromise the academic freedom that instructors at higher education institutions have been accustomed to, and drives educators to oppose these practices (Archer, 2008; Sanders-McDonagh \& Davis, 2018). Barnett (2003) says that quality assurance systems and practices that rely upon estimating student learning will, generally, hinder instructors, impede the improvement of their scholarly culture and prevent them from following up on their instincts. In taking this idea further, Morley (2003) states that governments utilize quality assurance as a way of enforcing greater control over higher education institutions and their presentation. This sort of control impacts the scholarly freedom of educators, thereby impacting their teaching and reducing opportunities for creativity. Hanson (2014) recommends encouraging creativity in students as well 
as teachers; doing so could support and enhance students' learning experiences and make them more meaningful; thus, attaining teaching excellence. In contrast, "measuring" teaching excellence can be done by evaluating the ability of students to apply or implement the knowledge and skills that shape their learning experiences (Hanson, 2014; Wilcox, 2021). Zukas and Malcolm (2002) accept that this control will have an antagonistic influence on the identities of educators, and on their values regarding instruction. Zukas and Malcolm (2002) are, in essence, concerned about novice instructors, who start their teaching experience within an arrangement of assurance and enhancement, and whose teaching values and identities are created and adjusted, as required.

Archer (2008) expresses similar concerns about the development of novice instructors' identities, as indicated by the performative frameworks of quality assurance and neo-liberalism. As quality assurance and quality enhancement are both dependent on setting rules and measuring standards, this idea may not fit the complexities of the education venture. Higher education institutions, as instructional organizations, depend on the association between the two integral parts of instructional establishments: the teacher and the student. As an outcome, proponents of educators who consider the student-teacher relationship are key to achieving teaching excellence.

\subsection{Teaching Excellence in Higher Education}

Wilcox (2021) concludes that the qualitative direction of any society is assisted by the excellence of teaching provided by higher education institutions. Providing high quality teaching to students has become one of the main concerns of policymakers, academic administrators and teachers at higher education institutions, in order to exemplify the notion of excellence.

Higher education institutions were among the first institutions in the world. Over the years, these institutions were subject to numerous fundamental changes and have faced enormous challenges due to the effect of the ever-changing environment in which they exist. These changes and challenges mean ideas, concepts, and roles relating to higher education vary among educators (Courtney, 2013). Accordingly, the meaning of higher education as a concept varies, from being a mere physical setting to abstract notions of acquiring information, where students are directly engaged with teachers in classrooms, which has always been considered to be the lively stage of teachers. However, this notion has been subjected to change, especially recently, due to drastic advances in technology, which mitigate distance, to the extent that it, ultimately, promotes online learning (Mve, 2021).

As the environment changes, teaching excellence increasingly becomes a fundamental objective of the missions of most higher education institutions. Teaching excellence is increasingly becoming the catchphrase of higher education in this century. However, the concept of teaching excellence has been the subject of considerable debate and scrutiny by myriads of political, social and academic philosophies. Zhu et al. (2013) explain that teachers at higher education institutions have the responsibility to address the interests of $21^{\text {st }}$ century students, by employing novel teaching techniques that differ from traditional 
ones. Gibson (2010) proclaims, "the time when academics in higher education could simply replicate the teaching methods that they experienced as students is quickly drawing to an end" (p. 3). Therefore, attaining teaching excellence entails tailoring and utilizing increasingly innovative and creative teaching techniques and learning activities to enhance the learning experiences of $21^{\text {st }}$ century students (Gibson, 2010; Zhu et al., 2013).

Academic administrators, professors, and students all possess different perspectives, depending on elements such as their beliefs about education, their customs, cultures, a country's level of development, their ages, experience, and even personalities. Accordingly, the literature is rich in serious attempts to offer relevant definitions and to identify the key components of teaching excellence (Faltis, 2012; Gourlay \& Stevenson, 2017; Oravec, 2017; Skelton, 2012; Wood \& Su, 2017).

Skelton (2005) categorizes understandings of teaching excellence into four categories: traditional, psychological, performative and critical. The traditional understanding of teaching excellence is based on teachers being knowledgeable about the subject matter they teach; their teaching strategy is mainly traditional lecturing. The psychological understanding of teaching excellence focuses on teacher-student relationships, while the performative understanding is based on teachers' concerns about meeting labour market demands. Finally, a critical understanding emphasizes the teacher giving students the opportunity to discuss critical issues related to their society. This categorization contributes to providing a unified definition of the teaching excellence of educators.

\subsection{Quality Assurance and Quality Enhancement Strategies: Monitoring Teaching Quality}

Most higher education institutions aim to offer the highest quality of education possible; accordingly, the purpose of their services is to strengthen and enhance students' learning experiences. With increasing globalization, along with the never-ending input of technology in the educational arena, cooperative learning has been demonstrated to have an edge over traditional teaching. In response to the radical transformation of teaching and learning, and an increased emphasis on student-centeredness and related interactive and cooperative learning, more attention is being paid to monitoring the performance of teachers and ensuring the quality of the teaching they provide to their students (A-Maawali \& Al-Siyabi, 2020; DeRijdta et al., 2006; Huang et al., 2013). Furthermore, the ranking of higher education institutions depends on multiple criteria, and the quality of teaching provided and criteria that relate to the learning that takes place are considered to be the most significant criteria that are relied on (Hauptman Komotar, 2020; Dembereldorj, 2018). These criteria encourage leaders of higher education institutions and policymakers to promote their monitoring processes related to the quality of teaching and learning, and to continuously improve the quality of education by addressing the main requirements of students, and elevating students' learning standards. 
Today, it is vital to consider processes or strategies that are needed to bridge the gap between "where a higher education institution is" and "where (this higher education institution) wants to be." Closing the gap involves structuring and executing quality improvements or upgrading techniques. Hence, facing or overcoming issues is an important element of quality assurance, and comprises quality upgrades or quality improvement techniques that are implemented to fulfil the identified guidelines.

According to the primary supposition of the supporters of quality assurance, attaining foreordained goals demonstrates the achievement of teaching excellence. Consequently, an immediate association appears among the three parts of quality: quality assurance, quality improvement and teaching excellence (Hariri, 2016; Salmi, 2020). Thus, quality upgrades or improvements function within the quality assurance framework, which administers or oversees all quality improvement systems adopted by a certain higher education institution.

\subsection{Models of Quality Assurance Performance Measurement}

The way higher education institutions decide to monitor their teaching quality is based on their level of understanding of quality management, and the philosophy they espouse. Consequently, specific higher education institutions have a habit of monitoring their educational standards in accordance with the quality assurance systems through which aim to achieve the identified standards (Nurjati, 2006). This approach warrants providing higher education institutions with control; thus, assuming a neoliberal ideology. In turn, other higher education institutions may choose a quality improvement or quality enhancement type of administration that ensures the enhancement of education by concentrating on the performance of teachers, which leads to teaching excellence (Skelton, 2012). Moreover, Mhlanga (2012, p. 1081) views quality improvement or quality enhancement in terms of "increased sharing of information, intellectual resources and research" within and among higher education institutions.

A significant number of higher education institutions prefer the "top-down" model, according to which they prescribe the strategies teachers are to follow. Other higher education institutions implement a "bottom-up" model, in an attempt to consider teachers' views on education. The Quality Assurance Academy, which was created in conjunction with the development of their project in June 2008, present two distinct views on quality improvement and enhancement. Some higher education institutions describe quality enhancement as constant enhancement of present practices, while others perceive quality enhancement as a strategy utilized to repair what is ineffective (Higher Education Academy, 2008). Because unanimity is lacking among teachers on the designation of quality, policymakers usually pursue assessment procedures based on explicit criteria. Moving on, teachers interpret these criteria into "SMART" objectives and key performance indicators, which are measured at different stages, and at institution, program, and course levels. Consequently, policymakers or administrators at higher education institutions set high standards for teachers' performance, so teachers can accurately illustrate the quality of their work in reference to their compliance with these standards and because they achieve the relevant objectives. 
Certain norms establish the quantifiable strategies that depict the nature of a specific organization, which ultimately energizes the setting of guidelines as a feature of a quality confirmation framework that is expected to support a higher education institution in measuring the work provided more effectively, and more critically, to advise the establishment, regarding their context and direction.

\subsection{Conceptual Model}

If higher education institutions wish to track whether teaching methods are in line with their teaching philosophy and theories, a "quality model" can be used. This concept, which stems from constructivism, is synonymous with student-centred learning, in which educators guide students to develop their own, unique knowledge (Gibbs, 2001; Cheng, 2018). Alternatively, higher education institutions can embrace a "quality enhancement model" if they need to evaluate the systems utilized by instructors to improve their education methodologies. This model includes professional development activities that assist instructors to improve their own education. Lastly, higher education institutions can use the "quality feasibility" model should they need to concentrate on recognizing and, at that point, eliminating all the snags that prevent the improvement of instruction. The selection of a model of quality depends on the design of a specific higher education institution.

According to Guest and Duhs (2003), the need to establish national quality assurance organizations or institutional quality assurance frameworks arose as a result of an increase in the number of students who qualified to be admitted to higher education institutions, and a reduction in the capital assigned to higher education institutions, both of which apply to KSA - the context of this study (Allahmorad \& Zreik, 2020). Consequently, quality assurance frameworks or organizations are required to assist students' education by monitoring the quality of education, as well as all university support by administration. This is accomplished by recognizing student learning outcomes and establishing criteria to assess them. Setting up a quality assurance system is, therefore, not an end in itself, but rather a means of achieving the end goal of providing quality education and learning. Quality assurance systems or organizations provide information to upper-level administration at institutional or national levels, which enables them to make informed decisions on the best way to achieve predetermined parameters (Mgaiwa, 2018).

\section{Research Methodology}

\subsection{Data Collection and Analysis}

The research design adopted by this study is a qualitative case study supported by an interpretivist paradigm, which depended on obtaining multiple perceptions, in order to lead and improve the understanding of the topic or concept under investigation (Creswell, 2013; McMillan \& Schumacher, 2014). The case study made triangulation possible, by facilitating a detailed exploration of perceptions from multiple sources, namely employees occupying different positions in the three universities under investigation in this study: faculty members, academic directors, and administrative staff members. 
Data analysis started with open coding to generate the codes, which were then organized into categories, followed by a reduction of categories to produce the themes. This research design was the best fit to answer the research questions, as it allowed the participants to speak up and express their perceptions freely (Creswell, 2013). Twelve 45-minute, one-on-one, in-depth semistructured interviews were conducted virtually with 12 participants who occupied academic and non-academic positions; the interviews were recorded via Zoom Cloud. The interviews included open-ended questions that were supported by relevant probing questions, when necessary. The open codes were generated after the recorded interviews had been transcribed verbatim. The interview questions that participants responded to are the following:

1. How do you perceive academic quality in higher education institutions?

2. What are the most important academic quality practices that exist in your institution?

3. What are the academic quality assurance practices that you think need improvement?

4. What is/are the practices that you think must be maintained?

5. What is/ are the practices that you think must be avoided?

6. How do you think these practices can be improved?

7. What are the academic services that are not assessed in your institution, but you think must be assessed or measured in higher education institutions?

\subsection{Recruitment and Sampling}

A purposive non-probability sample was selected (Merriam \& Tisdell, 2015) to provide the best representation of an academic and non-academic population of employees who were directly involved in quality assurance practices at three private higher education institutions. These selected universities have similar schools and academic programs. The sample comprised 12 participants: six faculty members, four program directors, one senior academic staff member, and one junior non-academic administrator. Participants were from three different universities, four different schools and from ten different programs at these universities. This sample ensured that different perspectives of various types of employees, occupying different positions, with different years of experience in various disciplines, would be elicited (Creswell, 2013). The researcher contacted the participants through their individual universities' research institutes. The researcher, as a faculty member and the former director of the quality assurance department of one of the selected universities, contacted the directors of the research centres in the selected universities and asked for their support to facilitate contacting prospective participants who were engaged in quality assurance processes. The emails contained a request to participate in the study, as well as an information page, and a consent form to complete. The participants were free to participate in and withdraw from the research at any time. 
Table 1. Sampling characteristics

\begin{tabular}{|c|c|c|c|c|}
\hline No. & Pseudonym & Position & School & $\begin{array}{c}\text { Years of } \\
\text { experience }\end{array}$ \\
\hline 1 & Liza & Program director & Art and Design & 25 \\
\hline 2 & Fensi & Faculty member & Art and Design & 3 \\
\hline 3 & Sally & Program director & Business & 15 \\
\hline 4 & Nadera & Faculty member & Business & 20 \\
\hline 5 & Leena & Faculty member & Business & 13 \\
\hline 6 & Najia & Faculty member & $\begin{array}{l}\text { Health Sciences and } \\
\text { Education }\end{array}$ & 10 \\
\hline 7 & Nina & Program director & $\begin{array}{l}\text { Health Sciences and } \\
\text { Education }\end{array}$ & 8 \\
\hline 8 & Marta & Program director & $\begin{array}{l}\text { Computer and } \\
\text { Engineering }\end{array}$ & 17 \\
\hline 9 & Berna & Faculty member & $\begin{array}{l}\text { Computer and } \\
\text { Engineering }\end{array}$ & 5 \\
\hline 10 & Seeta & Faculty member & General Education & 15 \\
\hline 11 & Tara & $\begin{array}{l}\text { Academic } \\
\text { administrative Staff } \\
\text { member }\end{array}$ & & 12 \\
\hline 12 & Katia & $\begin{array}{l}\text { Non-academic } \\
\text { administrative staff } \\
\text { member }\end{array}$ & & 22 \\
\hline
\end{tabular}

Source: Primary data. Own dataset.

\section{Results and Analysis}

Nobongoza (2019) reports that the perceptions about academic quality and relevant practices do not vary much between education institutions, though perceptions differ between faculty members and administrators at the same institution. This was evident from the responses obtained from the 12 participants during the interviews, which revealed differences in the perceptions of the different groups of interviewees (teachers, academic directors, non-academic directors) in the same group, between the three higher education institutions, and at the same institution.

\subsection{Academic Quality: Diverse Perceptions}

According to the literature, the concept of academic quality assurance varies from one participant to another, from encompassing related practices and incorporating relevant processes, to completing documents and meeting national and/or international standards (Dill, 2010; Skelton, 2012). To support this claim, participant Nina defined academic quality assurance as,

"making sure keeping in best practices so ensuring the education we are providing to the students, the content that we're providing the books and everything else is of a good quality and also that it is in line with our national accrediting standards"

while Marta emphasized the importance of "proper implementation of the quality assurance processes followed in the university". Liza considered academic quality to be the "completion of certain documents provided from the quality assurance office", while Sally defined it as, "meeting pre-identified standards". 
This variation in the participants' perceptions of what academic quality assurance is, can be explained in reference to the nature of the work of each participant and their contribution to this work. This was highlighted by the participant Nadera, who reported that "every person has his/her own added value to the teaching quality". This indicates that the participants themselves were aware of the variation in perceptions among higher education institution employees. This awareness emphasizes the holistic concept of academic quality that encompasses a set of processes that are followed in compliance with a set of policies and procedures, in order to meet specific standards (Weedmark, 2019). In this light, Tara said that academic quality is "very broad as it encompasses the measurement of the teaching practices, teaching styles and assessment tools". These divergent notions of academic quality assurance, was confirmed by Sally, who explained it as,
"the available infrastructure for all quality assurance related practices and documents. The set of policies and procedures that are aligned with the identified standards, allow for the comparison of the actual outcomes with the preplanned ones."

The importance of standards, the compliance of the education institution to these standards, and their effective implementation, was a concern raised by Katia, who acknowledged that "we do have standards, but who is implementing them? This question reveals the real concerns of participants - whether faculty members or administrators - about providing high quality teaching for students.

\section{Feedback: Continuous Improvement}

From another angle, academic quality assurance is represented by the continuous improvement of processes in response to feedback obtained from stakeholders (Tandberg \& Martin, 2019). In this regard, Katia confirmed that the evaluation system that exists at the university is comprehensive, and it assesses almost all services every year; nevertheless, this system has "to be taken more seriously". Katia explained this seriousness and expressed concerns about "where the results go and what happens to them and who benefits from them?" - in essence, is the quality assurance loop closed? Closing the loop is an indispensable process in quality assurance, which emphasizes the significance of the feedback obtained through the various evaluation processes and the immediate actions that need to be taken by the responsible parties to achieve improvements (Tandberg \& Martin, 2019). This matter was also emphasized by Sally, who agreed on the importance of obtaining feedback from the various stakeholders, "to benefit from their feedback in improving the practices and thus closing the loop". Nadera indicated that "closing the loop is not there ... communicating findings is not there ... therefore we do not see improvement in practice ... only more paperwork".

These comments highlight the awareness of the participants of the significance of the evaluation system, and indicate their awareness of the importance of the quality of the feedback this system provides, and that the feedback could pave their way to achieving teaching excellence. Feedback that gives more than a yes or no answer (such as whether a service exists or does not exist), but also provides stakeholders' suggestions about ways to improve, are particularly useful. 


\section{Enjoying Teaching vs. Excessive Paperwork}

The excessive paperwork that most higher education institutions require is considered to be as a waste of time (Seyfried \& Pohlenz, 2018), and tends to prevent faculty members at the university from thinking about their teaching, which should be their priority. This was stressed by Liza, who declared that "the paperwork should be reduced in favor of providing quality teaching." Nadera expressed concern about "making use of what is written in the papers and not just the completion of papers." Berna stated that, "the practices and documents are there, but who is reading these documents and who is benefiting from them?" Seeta said that paperwork is useless since "no one looks at it after completion," and therefore it does not lead to improvement. Berna added that the "endless paperwork that we need to do made me loose the enjoyment of teaching ... I want to enjoy teaching." In contrast, Fensi and Seeta expressed that they have no problem with the paperwork, which they regarded as necessary and reasonable, especially for curriculum review. Fensi asked, "how can we do curriculum review without these documents?"

Due to the variance in viewpoints on paperwork, I recommend that all academic quality assurance systems must be revised. It is critical that these processes, together with any associated paperwork, assist instructors and facilitate their teaching rather than being a burden on teachers, thereby jeopardizing teaching quality. The participants confirmed the importance of filling in the documents to indicate the achievement of the pre-identified standards, as well as following the appropriate procedures and processes. An example of these documents are the course syllabi, which include learning outcomes that the students are expected to achieve, and teaching strategies, and the assessment tools. Participants indicated that this syllabus needs "to be personalized" to reflect the teaching philosophies of the teachers, as well as "their creativity," as Najia and Liaza indicated respectively.

This explains that participants were aware of the significance of quality assurance and various other relevant processes. Nevertheless, the work that they need to do to complete these processes has to be reduced, so that they do not conflict with the efforts that teachers have to exert to provide the high quality teaching needed to achieve teaching excellence.

\section{Evaluation Practices: Improving Practices}

Evaluation of academic practices, whether internally or externally, constitute a core practice of quality assurance (Kettunen, 2015). This was confirmed by most of the participants in this study, who appreciate the various types of evaluations, especially those that clarify the items that need improvement to increase teachers' focus on the action plans that need to be developed in order to accomplish the improvements and upgrades. Liza (a program director) explained that "we invest in the low scored items to provide the suitable professional development for faculty to improve their practices." This was confirmed by Leena, who said that "class observations, course evaluation and program director evaluation make a perfect evaluation triangle that tells us a lot about the teaching and learning in classrooms." However, Najia expressed concern about the reliability of students' 
evaluation of instruction, as she believed that "students do not evaluate us thoughtfully ... they even do not read the items thoroughly ... they base their evaluation based on their grades and love to the teacher ... so, subjective and not objective."

Whether student evaluation of practices is valid is a concern that is not specific to higher education institutions in Saudi Arabia, but extends to universities outside the context of this study. In this regard, Stark (2014) considers the methods and statistics used to evaluate instructions by students as unsuitable; accordingly, he suggests employing additional types of evaluation.

\section{Discussion}

This study explored the academic quality assurance practices that higher education institutions should adopt in their journey towards teaching excellence. The study adopted a qualitative interpretive research design and utilized indepth, individual, semistructured interviews with 12 participants who were faculty members or academic administrators. The study concludes that these practices seem to be inexact, and do not necessarily provide the expected benefits or support that higher education institutions aspire to to provide the high quality teaching needed to achieve teaching excellence. This conclusion was reached despite the existence of quality assurance practices that are initiated by the quality assurance office or department, or even the deanships at the universities that participated in the study. Accordingly, these practices can be categorized into four groups, to provide the best answers to the research questions of this study. These groups are a) Must-keep practices, b) Must-add practices, c) Must-modify practices, and d) Must-avoid practices.

\section{a) Must-keep Practices}

According to the findings of this study, the most important practice that should be retained and even emphasized is the development and implementation of improvement plans. These plans are included in the documents of the national accrediting body to demonstrate when standards are being achieved. Among these documents is a course report that must be completed after a course has been taught. It explains the teaching practices applied in each course, the assessment tools and, most importantly, it includes an action plan for improvements for the course. The course reports along with the action plans set out the support needed by teachers, to be provided by various academic committees, in relation to completing the required documents and overseeing the development and implementation of improvement plans. This is supported by the evaluation of teaching practices that are undertaken by students and program directors, or any other external evaluation that is related to accrediting bodies.

\section{b) Must-add Practices}

Based on the findings of this research study, there is a need to assist and educate faculty and staff members to raise their awareness of all academic quality assurance practices, and so that they complete the relevant documents properly and in time. This education will make a significant contribution to enhancing the understanding of employees in general, and faculty members in particular, about 
quality assurance practices, to fostering their engagement, and increasing their interest in quality assurance work, "thus reducing their resistance," as Marta said. This was also emphasized strongly by Liza, who explained that "faculty members and staff have to understand what they are doing; quality assurance is not just completing and compilation of documents." In addition, Leena suggested that even "quality assurance officers must be educated to provide better help to faculty members and be able to answer all their questions." Being aware of and engaged in the development and implementation of quality assurance practices helps faculty members make sense of work related to ensuring quality that they must do and invest in to improve their teaching. This involvement will help to change their perceptions about this type of work, from the idea that it hinders teaching, to that it facilitates teaching.

\section{c) Must-modify Practices}

In accordance with the participants' responses, it is recommended that faculty members at higher education institutions are given the academic freedom to personalize their syllabi, in an attempt to reflect their specific efforts and creativity, and to pave the way for them to achieve teaching excellence. Academic freedom gives faculty members the opportunity to determine "what" and "how" to teach the course assigned to them (Nelson, 2010). The course syllabus, as claimed by Liza, "is not only a template to be completed; it mirrors the instructor and the course in one document." Academic freedom has always been highly appreciated by faculty members, who consider it as a right that they do not want to be compromised.

Furthermore, participants expressed concerns about the processes involved in appointing faculty members; they believed it affected the quality of teaching. Consequently, participants advised that the processes of appointing faculty members are revised and improved, to ensure that faculty members of a high caliber, who have previous teaching experience in higher education are appointed. Doing so can add value to teaching and learning at the university, through recruiting faculty members "who can introduce new experiences to our students", as stated by Katia. In this respect, Tara said that "the center of quality assurance needs to modify its processes to focus more on overseeing the teaching quality through monitoring the improvements included in the reports generated every year."

\section{d) Must-avoid Practices}

This study concludes by recommending the elimination of certain practices that participants consider of minimal or no value to academic quality. These practices include all work that is repeated, or documents that are duplicated. This was clarified by Nadera, who indicated that we need "to stop submitting documents of the same course for multiple sections." Nina emphasized the need to have appropriate "coordination among different departments or programs to reduce doing the same work twice or even more." This goal can be attained through "centralizing all quality assurance related work," as Leena recommended, and encouraging "collaborative work across the whole university," as Seeta advised. 


\section{Conclusion and Recommendations}

The increasing emphasis on quality assurance practices by management of higher education institutions is causing burnout of teachers, due to the extensive paperwork it demands. With the increasing number of higher education institutions that are seeking accreditation, policymakers, accrediting bodies, and the management of higher education institutions should revisit their current quality assurance practices. Doing so would be significant, as it would encourage management of higher education institutions to think about practices as means to improve the quality of teaching, promote academic freedom for faculty members, and to enhance creativity in teaching, to achieve teaching excellence.

Quality assurance procedures should emphasize providing feedback for improvement, closing the loop, reducing paperwork, minimizing job duplication, and, most importantly, training all employees about these procedures, in order to increase their involvement in these activities. Quality assurance techniques "are not mathematical formulas whose answers should be known beforehand," as a participant, Sally, stated. Quality assurance practices should not be a "box to contain teaching," as Marta cautioned. Let us reconcile teaching with the relevant quality assurance practices, to help teachers "enjoy teaching," as Najia announced, to be creative, and to attain teaching excellence. Quality assurance procedures should be beneficial for teaching and supportive of instructors.

\section{Limitations}

This study employed a qualitative technique to obtain detailed responses from people directly involved in quality-related tasks. However, due to the study's qualitative nature, the findings cannot be generalized. As an extension of this work, a quantitative analysis in both private and public higher education institutions is recommended.

\section{References}

Allahmorad, S., \& Zreik, S. (2020, April, 9). Education in Saudi Arabia. World Education News + Reviews. https://wenr.wes.org/2020/04/education-in-saudi-arabia

A-Maawali, W., \& Al-Siyabi, M. (2020). Impact of quality assurance on quality teaching among teachers in Oman higher education. Education Quarterly Reviews, 3(3), 334350. https://doi.org/10.31014/aior.1993.03.03.144

Anane, G. K., \& Addaney, A. (2016). Managing quality assurance in higher education: The case of the university of energy and natural resources, Ghana. Journal of Education and Practice, 7(22), 4-46. https://www.iiste.org/Journals/index.php/JEP/article/view/32561

Archer, L. (2008). The new neoliberal subjects? Young/er academics' constructions of professional identity. Journal of Education Policy, 23(3), 265-285. https://doi.org/10.1080/02680930701754047

Barnett, R. (2004). Beyond all reason: Living with ideology in the university. Society for Research into Higher Education and Open University Press. https://doi.org/10.1080/00221546.2004.11773584

Biggs, J. (2001). The reflective institution: Assuring and enhancing the quality of teaching and learning. Higher Education, 41(3), 221-238. https:// doi.org/10.1023/A:1004181331049 
Bollaert, L. (2014). A manual for internal quality assurance (IQA) in higher education (HE): With a special focus on Professional Higher Education (PHE). 9th EQAF Barcelona. Parallel Plenary Session 1, EURASHE.

Brittingham, B. (2009, 20 August). Quality assurance in higher education. USAID/EGATE/ED, Worldwide Education and Training Workshop.

Brookfield, S. D. (2017). Becoming a critically reflective teacher (2nd ed.). Jossey-Bass.

Cheng, L. (2018). Teaching model reform of performance management course based on the theory of constructivism. Open Journal of Business and Management, 6, 651-657. https://doi.org/10.4236/ojbm.2018.63049

Courtney, K. (2013). Adapting higher education through changes in academic work. Higher Education Quarterly, 67(1), 40-55. https://doi.org/10.1111/hequ.12002

Creswell, J. W. (2013). Qualitative inquiry and research design: Choosing among five approaches (3rd ed.). Sage.

Dembereldorj, Z. (2018). Review on the impact of world higher education rankings: Institutional competitive competence and institutional competence. International Journal of Higher Education, 7(3), 25-35.

DeRijdta, C., Tiquetb, E., Dochyb, F., \& Devolderc, M. (2006). Teaching portfolios in higher education and their effects: An explorative study. Teaching and Teacher Education, 22, 1084-1093. http://dx.doi.org/10.1016/j.tate.2006.07.002

Dill, D. D. (2010). Quality assurance in higher education: Practices and issues. In P. P. Peterson, E. Baker, and B. McGaw (Eds.), International Encyclopedia of Education, (3 ${ }^{\text {rd }}$ ed., pp. 377-383). http://dx.doi.org/10.1016/B978-0-08-044894-7.00833-2

Faltis, C. J. (2012). Introduction - new lives of teachers: Reflective stances and persistent learning. Teacher Education Quarterly, 39(1), 3-5. https://www.jstor.org/stable/23479559

Filippakou, O. (2011). The idea of quality in higher education: A conceptual approach. Discourse: Studies in the Cultural Politics of Education, 32(1), 15-28. https:// doi.org/10.1080/01596306.2011.537068

FINHEEC (2008). Audits of quality assurance systems of Finnish higher education institutions: Audit manual for 2008-2011. Finnish Higher Education Evaluation Council. www.kka.fi/files/147/KKA_1007.pdf

Gibbs, G. (2001) Analysis of strategies for teaching and learning. UK Government National Archives. http://www.hefce.ac.uk/Pubs/hefce/2001/01_37a.htm

Gibson, R. (2010) The "art" of creative teaching: implications for higher education. Teaching in Higher Education, 15(5), 607-613. https://doi.org/10.1080/13562517.2010.493349

Gourlay, L., \& Stevenson, J. (2017) Teaching excellence in higher education: Critical perspectives. Teaching in Higher Education, 22(4), 391-395. https:// doi.org/10.1080/13562517.2017.1304632

Guest, R., \& Duhs, A. (2003). Quality assurance and the quality of university teaching. Australian Journal of Education, 47(1), 40-57. https://doi.org/10.1177/000494410304700104

Hariri, R. (2016). Understanding teaching excellence in higher education in an Arab Country: The case of Lebanon (PhD thesis, University of Sheffield).

Hanson, S. (2014, November 13). Teaching excellence: Encouraging creativity. CTPC Spotlight [Blog]. https://blog.cptc.edu/feature_story/teaching-excellence-math-facultyencourages-creativity/

Hénard, F. (2010). Learning our lesson: Review of quality teaching in higher education. Organisation for Economic Cooperation and Development.

Huang, P., Chen, J., \& Zheng, W. (2013) A research on quality assurance in arts classroom teaching in higher education in China. Open Journal of Social Sciences, 1(1), 5-12. https://doi.org/10.4236/jss.2013.11002 
Hauptman Komotar, M. (2020). Discourses on quality and quality assurance in higher education from the perspective of global university rankings. Quality Assurance in Education, 28(1), 78-88. https://doi.org/10.1108/QAE-05-2019-0055

Higher Education Academy. (2008). Interim evaluation. A report to HEFCE, HEFCW, SFC, DELNI, Guild HE and UUK. Oakleigh Consulting.

Kettunen, J. (2015). Stakeholder relationships in higher education. Tertiary Education and Management, 21(1), 56-65. http:/ / dx.doi.org/10.1080/13583883.2014.997277

McMillan, J., \& Schumacher, S. (2014). Research in education: Evidence-based inquiry (7th ed.). Pearson.

Merriam, S. B., \& Tisdell, E. J. (2015). Qualitative research: A guide to design and implementation (4th ed.). Wiley.

Mgaiwa, S. J. (2018). Operationalising quality assurance processes in Tanzanian higher education: Academics' perceptions from selected private universities. Creative Education, 9(6), 901-918. https://doi.org/10.4236/ce.2018.96066

Mhlanga, E. (2012). Regionalisation and its impact on quality assurance in higher education. Creative Education, 3(Special Issue), 1079-1086. http://dx.doi.org/10.4236/ce.2012.326162

Morley, L. (2003). Quality and power in higher education. SRHE and Open University Press.

Mishra, S. (2007). Quality assurance in higher education. National Assessment and Accreditation Council, India, Commonwealth of Learning, Canada. http://oasis.col.org/bitstream/handle/11599/101/QAHE_Intro.pdf?sequence= 1

Mve, J. P. (2021). Revisiting the causes and meaning of higher education massification in sub-Saharan Africa: Evidence from Cameroon. Open Journal of Social Sciences, 9, 188-211. https://doi.org/10.4236/jss.2021.94015

Nelson, C. (2020, December 21). Defining academic freedom. Inside Higher Ed. https://www.insidehighered.com/views/2010/12/21/defining-academicfreedom

Nobongoza, V. E. (2019). A perspective on quality improvement plan implementation practices: A case study [Master's dissertation, University of the Free State, Bloemfontein].

Nurjati, I. S. (2006). Quality management in education: Self-evaluation for quality improvement. HM Inspectorate of Education. https://www.coursehero.com/file/95020856/Quality Management in Education-Self-evaluation for quality improvement.pdf

Oravec, J. A. (2017). The manipulation of scholarly rating and measurement systems: Constructing excellence in an era of academic stardom. Teaching in Higher Education, 22(4), 423-436. https://doi.org/10.1080/13562517.2017.1301909

Salmi, J. (2020). Tertiary education is indispensable to achieve the sustainable development goals. International Higher Education, 100, 14-15.

Sanders-McDonagh, E., \& Davis, C. (2018). Resisting neoliberal policies in UK higher education: Exploring the impact of critical pedagogies on non-traditional students in a post-1992 university. Education, Citizenship and Social Justice, 13(3), 217-228. https://doi.org/10.1177/1746197918793061

Seyfried, M., \& Pohlenz, P. (2018). Assessing quality assurance in higher education: Quality managers' perceptions of effectiveness. European Journal of Higher Education, 8(3), 258-271. https://doi.org/10.1080/21568235.2018.1474777.

Skelton, A. (2005). Understanding teaching excellence in higher education: Towards a critical approach. Routledge.

Skelton, A. (2012). Colonised by quality? Teacher identities in a research-led institution. British Journal of Sociology of Education, 33(6), 793-811. https://doi.org/10.1080/01425692.2012.692047 
Stark, P. (2014, October 14). Do student evaluations measure teaching effectiveness? Berkeley Blog [Blog]. https://blogs.berkeley.edu/2013/10/14/do-student-evaluationsmeasure-teaching-effectiveness/

Tandberg, D. A., \& Martin, R. R. (2019). Quality assurance and improvement in higher education: The role of the states. The State Higher Education Executive Officers Association (SHEEO) content/up;oads/2019/05/SHEEO_Qualityassurance.pdf

Weedmark, D. (2019, December 12). Quality assurance policies and procedures. Bizfluent. https:/ / bizfluent.com/about-5485669-quality-assurance-policiesprocedures.html

Wilcox, K. (2021). Interrogating the discourses of "teaching excellence" in higher education. European Educational Research Journal, 20(1), 42-58. https://doi.org/10.1177/1474904120944783

Wood, M. \& Su, F. (2016). What makes an excellent lecturer? Academics' perspectives on the discourse of "teaching excellence" in higher education. Teaching in Higher Education, 22(4), 451-466. https://doi.org/10.1080/13562517.2017.1301911

Zhu, C., Wang, D., Cai, Y., \& Engels, N. (2013). What core competencies are related to teachers' innovative teaching? Asia-Pacific Journal of Teacher Education, 41(1), 9-27. https:// doi.org/10.1080/1359866X.2012.753984

Zukas, M., \& Malcolm J. (2002, October 3). Playing the game: Regulation and scrutiny in academic identities [Paper presentation]. Invites seminar. University of Sheffield. 